\title{
Effect of High Pressure Treatment on Interfacial Properties, Structure and Oxidative Stability of Soy Protein Isolate-Stabilized Emulsions
}

\author{
Shuang $\mathrm{Chen}^{1+}$, Xiaodan Wang ${ }^{1+}$, Yeye $\mathrm{Xu}^{2}$, Xiaonan Zhang ${ }^{1}$, Xibo Wang ${ }^{1, *}$, and \\ Lianzhou Jiang ${ }^{1}$ \\ ${ }^{1}$ College of Food Science, Northeast Agricultural University, Harbin 150030, CHINA \\ ${ }^{2}$ Haofu international, Shanghai, 201100, CHINA \\ + Indicates that the two authors contribute consistently to this article
}

\begin{abstract}
The effect of high pressure homogenization (HPH) treatment (40 to 200MPa) on the structure, interfacial properties and oxidative stability of soy protein isolate emulsions were investigated. After HPH process, emulsifying activity (EAI) and emulsion stability (ESI) could be improved by $114 \%$ and $125 \%$, percentage of protein adsorbed to oil-in-water emulsions significantly improved when the pressure was not more than 160 MPa. SDS-PAGE showed that the HPH caused more low molecular mass subunits as the samples were treated below 160 MPa. FTIR traced the changes of four conformations in the secondary structure. Within a suitable pressure range, the apparent viscosity increased with the increasing of pressure, which reflected shear thinning; rheological measurement of emulsions showed G'>G", G' and G" both increased significantly with frequency increasing; emulsions treated by HPH had better oxidative stability. This paper suggested the HPH was a useful method for preparation the highly viscous and stable emulsions.
\end{abstract}

Key words: emulsion, soy protein isolate, high pressure homogenization, interfacial properties, oxidative stability

\section{Introduction}

An emulsion is made up with two immiscible liquids, for example, oil and water. One liquid is dispersed as droplets (the internal phase or dispersed) in the other phase (continuous or external phase $)^{1)}$. In food industry, emulsion is very common and it includs two types, milk, cream, salad dressing and mayonnaise are oil-in-water emulsion, margarine and butter are water-in-oil emulsion. Emulsion is a thermodynamic unstable system effected by a variety of physicochemical mechanisms and tends to break down over time. Emulsifier, such as soy protein isolate, can adsorbed onto the droplets surface, lowering interfacial tension, forming viscoelastic films at the oil-water interface, reducing the influence of particle migration or particle size change thereby improving the physical stability ${ }^{2-4)}$.

Soy protein isolate (SPI) has a protein content above $90 \%$ and is mainly made up with globulin (11S) and $\beta$-conglycinin (7S). SPI has attracted considerable attention and is widely used in food products due to its excellent functional properties (solubility, foaming properties, waterbinding capacity, emulsification and water-holding capaci- ty), abundant supply, low cost, renewability and biocompatibility $^{5-9)}$. For nutritional values, SPI contains nearly 20 kinds of amino acids and among them there are many essential amino acids. It is rich in nutrients and contains no cholesterol. It is one of the few alternative animal protein varieties in plant protein. In terms of functionality, the addition of SPI can improve the texture, flavor and taste of the product, so it is a very common material in meat products, dairy products and pasta products ${ }^{10)}$. In addition, SPI is regarded as a promising raw and attractive material because of its biodegradable properties. It could be used as packaging and edible films, plastics, adhesives and various binders ${ }^{11)}$. However, SPI also has some shortcomings compared to other proteins, such as poor solubility, which limits its application. It has been reported that SPI could be modified by some methods contain physical, chemical and biological methods which improved physicochemical and interfacial properties ${ }^{12}$.

High pressure homogenization (HPH) is an non thermal technology which was frequently used to produce emulsions. During the HPH process, under a certain pressure

\footnotetext{
*Correspondence to: Xibo Wang, College of Food Science, Northeast Agricultural University, Harbin 150030, CHINA

E-mail: wangxibo@neau.edu.cn

Accepted March 1, 2019 (received for review November 20, 2018)

Journal of Oleo Science ISSN 1345-8957 print / ISSN 1347-3352 online

http://www.jstage.jst.go.jp/browse/jos/ http://mc.manusriptcentral.com/jjocs
} 
fluid is forced through some micrometers orifice, the fluid accelerates to a very high velocity during passing a very short distance, and the fluid is disrupted particles down to the submicron range undergoes the effect of cavitation, shear and turbulence, which take place at the outlet of the value gap ${ }^{13,14)}$. HPH plays an important role in preparation and stabilization of emulsion. During the process of $\mathrm{HPH}$, the natural structure and many processing characteristics of the protein have changed. Wang et al. ${ }^{15)}$ found that protein structure was more stretched, subunit appeared dissociation and reunion after HPH, thereby the solubility and emulsifying properties of globulin were remarkably improved. Xu et $a l .{ }^{16)}$ pointed that there was a positive correlation between the flexibility of SPI and emulsifying properties under the condition of HPH, HPH could improve the emulsifying properties of SPI. A result got by Hebishy et $a l .{ }^{17)}$ showed that the HPH together with sodium caseinate has the ability to produce emulsions which are physically stable against coalescence and creaming with reduced particle size. Fernandez-Avila et $a l .{ }^{18)}$ investigated the effect of HPH from 100 to $300 \mathrm{MPa}$ compared to conventional homogenization at $15 \mathrm{MPa}$ oxidative stability of emulsions stabilized by SPI, and found that HPH technology was a suitable method to produce emulsions with a higher oxidative stability. Hebishy et $a l .{ }^{19)}$ had finished a similar study that explored the effect of HPH on oxidative stability of WPI emulsions, and got a similar result.

Although several researchers have studied the effect of HPH on structure, physical stability, only some researchers have studied the interfacial properties and oxidative stability $^{20,21)}$. Except that, they often selected $100 \mathrm{MPa}$ or bigger pressure as the interval and there is not much comprehensive evidence to associated HPH function with the properties changes of emulsions. In this paper, we have set 20 $\mathrm{MPa}$ as an interval to investigate the all-sided effect of HPH on the structure, interfacial properties and oxidative stability of oil-in-water emulsion stabilized by SPI.

\section{Materials and methods \\ 2.1 Materials}

Soybean was obtained from the Northeast agricultural university Soybeans Research Institute(Heilongjiang, China). Soybean oil was purchased from Jiusan Company (Heilongjiang, China). All other chemicals used were of analytical grade.

\subsection{Preparation of emulsions}

\subsubsection{Preparation of SPI}

According to the method adapted from Sorgentini et $a l .{ }^{22)}$. Soybean was crushed and passed through a 60 mesh sieve to obtain soy flour. The resulting soybean flour was defatted by extracting with ether according to the soxhlet method. SPI was prepared from defatted soy flour by alkalisolution and acid-isolation and the protein content determined by kjeldahl determination methods was $90.22 \pm$ $0.44 \% \mathrm{~W} / \mathrm{W}(\mathrm{N} \times 6.25)$.

2.2.2 Preparation of SPI stock solution

The SPI stock solution $(0.5 \% \mathrm{w} / \mathrm{v})$ was prepared by dispersing the SPI powder in phosphate buffer solution $(0.2$ $\mathrm{mol} / \mathrm{L}, \mathrm{pH} 7.0$ ) and was stirring for 2 hours at room temperature $\left(25^{\circ} \mathrm{C}\right)$. The stock solution was stored overnight at $4^{\circ} \mathrm{C}$ to allow protein hydration completely.

2.2.3 Homogenization treatments

After hydration, SPI stock solution and soybean oil were equilibrated at $25^{\circ} \mathrm{C}$ before blending. Pre-emulsions were prepared by mixing $400 \mathrm{~mL} 0.5 \%(\mathrm{w} / \mathrm{v})$ SPI stock solution and $100 \mathrm{~mL}$ soybean oil (content of oil is $20 \%$ ) using an Ultra Turrax model T18 homogenizer(IKA, Germany) for $1 \mathrm{~min}$ at $10800 \mathrm{rpm}$. The pre-emulsions were further homogenized at 40,60, 80,100,120,140,160, 180 and 200 MPa once by high-pressure homogenizer (APV-2000, UK). After that, the temperature of the emulsions at the outlet was measured.

\subsection{Emulsifying activity (EAI) and emulsion stability (ESI)}

The EAI and ESI were measured based on the method described by Tang $e t a l{ }^{23)}$. The SPI samples treated by $\mathrm{HPH}$ were diluted to $2 \mathrm{mg} / \mathrm{mL}$, and mixed with soybean oil at a volume ratio of $3: 1$, then the protein dispersion was homogenized at $10800 \mathrm{rpm}$ for $1 \mathrm{~min}$. At $0 \mathrm{~min}$ and $10 \mathrm{~min}$, $50 \mu \mathrm{L}$ samples were collected from the bottom of the emulsions were quickly added into $5 \mathrm{~mL} 0.1 \%$ SDS solution, fully mixed on a vortex mixer, the absorbance at $500 \mathrm{~nm}$ were measured by UV-visible spectrophotometer and the emulsifying activity (EAI) was expressed by the absorbance $\mathrm{A}_{0}$, ESI was calculated by the following equations:

$$
\begin{aligned}
& E S I=\frac{10 A_{0}}{A_{0}-A_{10}} \\
& \text { ESI: Emulsion stability, min } \\
& \mathrm{A}_{0} \text { : The absorbance at } 0 \text { min } \\
& \mathrm{A}_{10} \text { : The absorbance at } 10 \text { min }
\end{aligned}
$$

\subsection{Adsorbed protein percentage (C\%)}

Adsorbed protein percentage of emulsion was determined according to the method of Desrumaux et al. ${ }^{21)}$ with slightly modified. $50 \mathrm{~mL}$ fresh emulsions were poured into centrifuge tubes. The tubes were centrifuged (15000rpm, $45 \mathrm{~min}$ ) to separate the emulsions. The creamed oil droplets are at the top of the tube and the aqueous phase of the emulsion, at the bottom. The supernatant (the cream) was carefully removed from the aqueous phase using a syringe. Emulsion samples were centrifuged again at $15000 \mathrm{~g}$ for 45 min, collecting the liquid at the bottom and the protein content of unabsorbed protein $\left(\mathrm{C}_{\mathrm{i}}\right)$ was determined in triplicate by the micro-kjeldahl method $(\mathrm{N}=6.25)$. Adsorbed protein percentage $(\mathrm{C} \%)$ was calculated as 
$C(\%)=\frac{C_{0}-C_{i}}{C_{0}} \times 100 \%$

$\mathrm{C}_{0}$ : Protein content in the initial emulsion

$\mathrm{C}_{\mathrm{i}}$ : The content of unabsorbed protein in the emulsion

\subsection{Electrophoresis (SDS-PAGE)}

Molecular weight distribution of proteins treated by $\mathrm{HPH}$ were evaluated by Sodium dodecyl sulfate-polyacrylamide gel electrophoresis (SDS-PAGE) under reducing conditions, according to Laemmli et al. ${ }^{24)}$ with modification. In this study, $12 \%$ resolving gel and stocking gel were used. The protein sample was diluted to $5 \mathrm{mg} / \mathrm{mL}$, the protein sample mixed with loading buffer at 4:1, and the amount of the sample was $10 \mu \mathrm{L}$. The water was bathed in a water bath at $100^{\circ} \mathrm{C}$ for $3 \mathrm{~min}$ before electrophoresis. When the electrophoresis started, the set voltage was $90 \mathrm{~V}$. After the sample enters the separation gel, changed the voltage to $120 \mathrm{~V}$. When the strip runs to the bottom of the separation gel 1 $\mathrm{cm}$, the power is turned off, and the film is taken out and stained with Coomassie brilliant blue staining solution for $20 \mathrm{~min}$, and decolorized with methanol-glacial acetic acid until liquid transparent.

\subsection{Fourier transform infrared spectroscopy (FTIR)}

The protein samples treated under different HPH pressure were freeze-dried. Mixing $2 \mathrm{mg}$ freeze-dried samples with $200 \mathrm{mg} \mathrm{KBr}$, then pressed the mixed powder in $\mathrm{KBr}$ windows to form a solid thin film at room temperature before measurement. A Fourier transform infrared spectrometer was used to full-band (4000-400 $\left.\mathrm{cm}^{-1}\right)$ scanning, resolution was set to $4 \mathrm{~cm}^{-1}$, the number of scans was 32 times. The PeakFit 4.12 software was used to fit and analysis the dates and the secondary structure content of the protein was calculated.

\subsection{Optical microscope}

The emulsions microstructure was examined under an optical microscope. Emulsions were gently agitated in a glass test tube before analysis to ensure that they were uniform. A few drops of emulsions were put on a glass slide and fully covered with a cover slid. The microscope magnification of $100 \times$ was employed.

\subsection{Rheological measurement}

\subsubsection{Apparent viscosity}

The apparent viscosity of emulsions was analyzed using a rotary rheometer (Discovery, America) with a $40 \mathrm{~mm}$ diameter paraller plate at $25^{\circ} \mathrm{C}$. The shear rate was ranging from 0.01 to $100 \mathrm{~S}^{-1}$, the number of sampling point was 30 , the point was $5 \mathrm{~S}$, and the balance time is $1 \mathrm{~min}$. Samples were held at room temperature 15 min integration before measurements, then aspiration $2 \mathrm{~mL}$ of emulsions to the clamp gap and the perimeter were covered with a thin layer of silicone oil to prevent the sample dehydration.

\subsubsection{Elastic modulus and viscous modulus}

The Elastic modulus and lost modulus were measured by a rotary rheometer (Discovery, America) with a $40 \mathrm{~mm}$ diameter paraller plate. Frequency sweep tests $(0.1-10 \mathrm{~Hz})$ were carried out in the linear regime, at constant strain $(0.5 \%)$ at $25^{\circ} \mathrm{C}$.

\subsection{Analysis of lipid oxidation}

\subsubsection{Peroxide value}

Emulsions were storage in incubator at $50^{\circ} \mathrm{C}$ for 12 days to promote the process of oxidation. The samples were taken every two days and peroxide value were determined. The peroxide value of the SPI-stabilized emulsions were evaluated by the method according to Shao et $a l^{25)}$, with a few modifications. In brief, $0.2 \mathrm{~mL}$ emulsions were mixed with $1.5 \mathrm{~mL}$ isooctane/isopropanol (3:1, v/v) by vortex. The mixtures were centrifuged at $3400 \mathrm{~g}$ for $2 \mathrm{~min}$. Then the organic solvent phase which collected by centrifugation were mixed with $2.8 \mathrm{~mL}$ methanol/butanol $(2: 1, \mathrm{v} / \mathrm{v})$. Following that, the mixtures were reacted with $15 \mu \mathrm{L}$ of $0.3 \mathrm{~g} /$ $\mathrm{mL}$ ammonium thiocyanate and $15 \mu \mathrm{L}$ ferrous iron solution (prepared by mixing $0.264 \mathrm{M} \mathrm{BaCl}_{2}$ and $0.288 \mathrm{M} \mathrm{FeSO}_{4}$ ) for $20 \mathrm{~min}$ at room temperature. The absorbance of the resultant solutions were measured at $510 \mathrm{~nm}$ by an UNICO Spectro Quest ${ }^{\mathrm{TM}} 2800$ UV/VIS Spectrophotometer(United Products \& Instruments Inc., New Jersey, USA). Peroxide value was determined using a standard curve made from cumene hydroperoxide.

2.9.2 Thiobarbituric acid-reactive substances (TBARs)

The method of Sørensen and Jørgensen ${ }^{26)}$ was adapted to determine the secondary oxidation products, thiobarbituric acid-reactive substances (TBARs). In brief, $3 \mathrm{~mL}$ emulsions and $6 \mathrm{~mL}$ of trichloracetic acid (TAC) reagent $(7.5 \%, \mathrm{w} / \mathrm{v})$ were mixed in test tubes by vortex. The $1 \mu \mathrm{m}$ microporous membrane were used to filtered the resultant mixtures after $20 \mathrm{~min}$ the TCA addition. $2 \mathrm{~mL}$ filtered and thiobarbituric acid $(\mathrm{TBA})$ reagent $(0.8 \%, \mathrm{w} / \mathrm{v})$ were placed in test tubes and mixed by vortex. The resultant mixtures were heated in a water bath $\left(95^{\circ} \mathrm{C}\right)$ for $15 \mathrm{~min}$, and then cooled in an ice-bath to reduce the reaction process. The absorbance of the final extracts was recorded at $532 \mathrm{~nm}$. The TBARS concentration (mmol/L of emulsion) was determined according to a standard curve with 1, 1, 3, 3-tetraethoxypropane.

\subsection{Statistical analysis}

All experiments were determined in triplicate and results were expressed as means \pm standard deviations. The variance (ANOVA) of date was carried out by SPSS 19 Statistical software followed by Duncan's Multiple Range Test $(p<0.05)$. The date of Fourier transform infrared spectroscopy were fitted and analyzed using The PeakFit 4.12 software. Origin 9 software was applied to figure drawing. 


\section{Results and discussion}

\subsection{The temperature of the emulsions at the outlet}

The temperature of the emulsions at the outlet were measured after $\mathrm{HPH}$ and it increase $2 \sim 5^{\circ} \mathrm{C}$ per $20 \mathrm{MPa}$ from the pressure $0.1 \mathrm{MPa}$ (atmospheric pressure) to 200 $\mathrm{MPa}$ (Table 1). When the pressure was $140 \mathrm{MPa}$, the temperature reached $44.2^{\circ} \mathrm{C}$. The result of our experiment is same with Fernándezávila et $a l^{27)}$. During the process, emulsions undergo deformation, droplets break up, SPI adsorb to the interface formed between phases and collision, and possible recoalescence of oil droplets ${ }^{28)}$. The increase of temperature during HPH was contributed to the fluid passes through the value gap quickly and multiple forces work together, multiple forces were transformed into thermal energy, which contained high turbulence, shear, cavitation forces and kinetic energy ${ }^{14,20)}$.

\subsection{Emulsifying properties and adsorbed protein percentage}

The emulsifying properties and adsorbed protein percentage of emulsions were showed in Table 1. When the homogenization pressure was not more than $160 \mathrm{MPa}$, the emulsifying activity increased with the increase of homogenization pressure, and got maximum at $160 \mathrm{MPa}$, increased by $114 \%$, then the emulsifying activity showed a downward trend. The change of the emulsion stability with the homogenization pressure was similar to the emulsifying activity with the homogenization pressure. When the pressure was $180 \mathrm{MPa}$, increased by $125 \%$, the emulsion stability was highest. Adsorbed protein percentage is an important parameter to characterize the stability of emulsion that, in general, the higher the concentration of the interface protein, the stabler the emulsion was ${ }^{25)}$. The result of the adsorbed protein percentage was consistent with the result of the emulsifying properties. This indicated that there was a correlation between emulsion interface protein concen- tration and protein emulsifying ability. In this study, the result might attribute to the changes of structure and flexibility. Undergo the HPH process, flexibility of SPI was enhanced, SPI spatial structure was unfolded, and the hydrophobic group originally contained inside of the molecule was exposed, which enhanced the lipophilicity of the protein, thereby improving the efficiency of SPI adsorbed to the oil-water interface, the macroscopic performance is an improvement in protein emulsifying ability ${ }^{16)}$. Similar results were also observed for peanut $\operatorname{protein}^{29)}$, lupin $\operatorname{protein}^{30)}$, whey protein ${ }^{31)}$ and hazelnut meal proteins ${ }^{32)}$. When the pressure reached a certain threshold, the thermal generated by HPH was increased, and mechanical effect and the thermal effect interact to cause the protein to be denatured, which reduced surface hydrophobicity and emulsifying properties was lowered. Subirade et $a l^{33)}$ found that the tertiary structure of $\beta$-lactoglobulin changed significantly and the emulsification properties of the protein were significantly improved after HPH. Puppo et $a l .{ }^{34)}$ also confirmed that HPH could be used to produce the emulsions with higher percentage of adsorbed proteins, smaller droplet size and better emulsifying activity.

\subsection{Polyacrylamide gel electrophoresis (SDS-PAGE) of SPI}

SDS-PAGE was employed to observe the change in protein molecular weight after treated by $\mathrm{HPH}$ and the results are summarized in Fig. 1. As seen, all samples showed five bands obviously $\mathrm{A}, \mathrm{B}, \alpha, \alpha^{\prime}$ and $\beta$. When the emulsions were homogenized from $40 \mathrm{MPa}$ to $140 \mathrm{MPa}$, there are lower molecular weight protein A and B, no formation of high molecular weight protein aggregates. Under the condition of $\mathrm{HPH}$, partial SPI unfolding and exposing reactive sulfhydryl groups which could have an interchange reactions with disulfide between protein molecules adsorbed at the interface, thereby the surface viscosity of the

Table 1 Effect of HPH on the temperature of the material outlet, emulsifying properties and adsorbed protein percentage.

\begin{tabular}{ccccc}
\hline $\begin{array}{c}\text { homogenization } \\
\text { pressure }\end{array}$ & $\begin{array}{c}\text { the temperature of the } \\
\text { material outlet }\left({ }^{\circ} \mathrm{C}\right)\end{array}$ & EAI $\left(\mathrm{A}_{0}\right)$ & ESI $(\mathrm{min})$ & $\begin{array}{c}\text { adsorbed protein } \\
\text { percentage }(\%)\end{array}$ \\
\hline $0.1 \mathrm{MPa}$ & $24.45 \pm 1.55^{\mathrm{a}}$ & $0.4453 \pm 0.0044^{\mathrm{a}}$ & $11.7631 \pm 0.1144^{\mathrm{a}}$ & $86.731 \pm 0.233^{\mathrm{a}}$ \\
$40 \mathrm{MPa}$ & $30.10 \pm 0.20^{\mathrm{b}}$ & $0.4547 \pm 0.0064^{\mathrm{b}}$ & $13.3820 \pm 0.0857^{\mathrm{b}}$ & $89.749 \pm 0.159^{\mathrm{b}}$ \\
$60 \mathrm{MPa}$ & $31.85 \pm 0.55^{\mathrm{b}}$ & $0.4647 \pm 0.0051^{\mathrm{c}}$ & $13.7357 \pm 0.1308^{\mathrm{c}}$ & $90.6328 \pm 0.131^{\mathrm{c}}$ \\
$80 \mathrm{MPa}$ & $34.00 \pm 0.10^{\mathrm{c}}$ & $0.4740 \pm 0.0012^{\mathrm{d}}$ & $13.8787 \pm 0.0831^{\mathrm{d}}$ & $91.676 \pm 0.344^{\mathrm{d}}$ \\
$100 \mathrm{MPa}$ & $39.20 \pm 1.30^{\mathrm{d}}$ & $0.4763 \pm 0.0011^{\mathrm{e}}$ & $13.9644 \pm 0.1126^{\mathrm{e}}$ & $91.956 \pm 0.117^{\mathrm{e}}$ \\
$120 \mathrm{MPa}$ & $42.00 \pm 1.70^{\mathrm{e}}$ & $0.4793 \pm 0.0078^{\mathrm{f}}$ & $14.1836 \pm 0.1274^{\mathrm{f}}$ & $93.572 \pm 0.203^{\mathrm{f}}$ \\
$140 \mathrm{MPa}$ & $44.20 \pm 2.00^{\mathrm{f}}$ & $0.4865 \pm 0.0035^{\mathrm{g}}$ & $14.2881 \pm 0.1229^{\mathrm{g}}$ & $94.149 \pm 0.195^{\mathrm{g}}$ \\
$160 \mathrm{MPa}$ & $46.50 \pm 2.70^{\mathrm{g}}$ & $0.5077 \pm 0.0012^{\mathrm{h}}$ & $14.5386 \pm 0.1356^{\mathrm{h}}$ & $95.632 \pm 0.246^{\mathrm{h}}$ \\
$180 \mathrm{MPa}$ & $49.30 \pm 3.40^{\mathrm{h}}$ & $0.5010 \pm 0.0050^{\mathrm{i}}$ & $14.6949 \pm 0.1379^{\mathrm{i}}$ & $95.138 \pm 0.143^{\mathrm{i}}$ \\
$200 \mathrm{MPa}$ & $52.15 \pm 3.95^{\mathrm{i}}$ & $0.4995 \pm 0.0085^{\mathrm{j}}$ & $14.5836 \pm 0.1656^{\mathrm{j}}$ & $95.962 \pm 0.307^{\mathrm{j}}$ \\
\hline
\end{tabular}




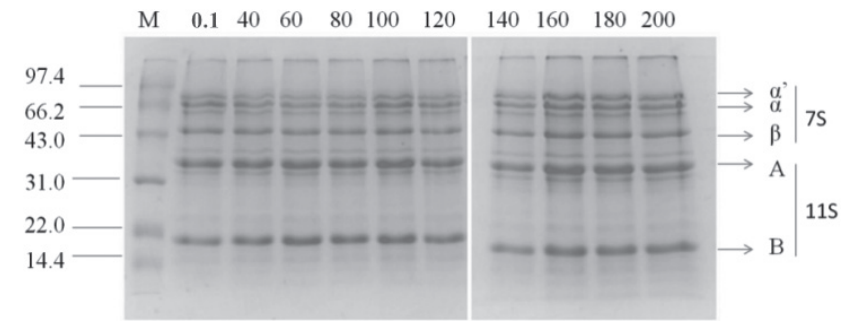

Fig. 1 SDS-PAGE patterns of soybean protein isolate under HPH.

emulsions increased, which could improve the stability of these emulsions ${ }^{35)}$. However, when the pressure increased to $160 \mathrm{MPa}$, it can be seen that, there are some formation of aggregates with molecular weight above $66.2 \mathrm{kDa}$. Therefore, the formation of high molecular weight aggregates was promoted by pressure, although the temperature not reached the denaturation temperature ${ }^{36)}$. The change of protein bands intensity might have an association with protein solubility. Saricaoglu et $a l .{ }^{31)}$ who study on the effect of high pressure homogenization on functional of hazelnut meal proteins have account for that the slightly decreased of protein band intensity could be related with decreasing solubility of proteins, when homogenization pressure increased to $150 \mathrm{MPa}$.

\subsection{FTIR}

As shown in Table 2, the secondary structure of the untreated sample is mainly $\beta$-sheet. For the HPH treated samples, as the homogenization pressure increases, the content of $\beta$-sheet and $\beta$-turn gradually increase, and the random coil also has an increasing trend, the $\alpha$-helix structure showed a decreasing trend which is the most abundant and stable structure in the protein molecule, and it has a tight cavity-free structure. The existence of $\alpha$-helix is not conducive to change the structure of $\mathrm{SPI}^{37)}$. The pres- ence of $\beta$-sheet, $\beta$-turn and random coil structures is beneficial to increase the flexibility of SPI. Therefore, the effect of HPH makes the spatial structure of soybean protein molecules more stretched, which is consistent with the structure of ultraviolet scanning spectroscopy and endogenous fluorescence spectroscopy put forward by $\mathrm{Xu}^{16)}$.

\subsection{Microstructure and emulsions}

The microstructure of the protein emulsions after different HPH was shown in Fig. 2. The combination of untreated protein and the oil phase was not tightly, and oil phase quickly aggregates to form droplets. The emulsion is unstable. As the homogenization pressure increased from 40 $\mathrm{MPa}$ to $140 \mathrm{MPa}$, the droplet size decreased and emulsions showed more uniform with no obvious oil drops. This was attributed to the fact that when the homogenization pressure was increased, emulsions undergo more intense turbulence, shearing, and cavitation, making protein easier to enter the oil-water interface, thereby making the protein and oil droplets more tightly combined and increasing the stability of emulsions. There are some large aggregates were observed in these emulsions as the homogenization pressure increased from $160 \mathrm{MPa}$ to $200 \mathrm{MPa}$, it due to the internal heat generation during high pressure homogenization, the temperature of the material outlet increased, some protein aggregated and obvious oil drops appeared. The results of the optical microscope are consistent with the results of SDS-PAGE and FTIR, they all showed the effect of $\mathrm{HPH}$ on protein structure.

\subsection{Rheological of emulsions}

\subsubsection{Apparent viscosity}

Viscosity reflects the rheological properties of a liquid material, which is a characteristic of the intermolecular attraction in a liquid or fluid. The viscosity of the emulsion is largely influenced by the hydrodynamic properties of the protein components such as relative molecular mass, size,

Table 2 SPI secondary structure content under different high pressure homogenization conditions.

\begin{tabular}{ccccc}
\hline $\begin{array}{c}\text { homogenization } \\
\text { pressure }\end{array}$ & $\alpha$-helix (\%) & $\beta$-sheet $(\%)$ & $\beta$-turn (\%) & random coil (\%) \\
\hline $0.1 \mathrm{MPa}$ & 18.75 & 36.70 & 27.21 & 17.34 \\
$40 \mathrm{MPa}$ & 17.19 & 36.66 & 28.14 & 18.01 \\
$60 \mathrm{MPa}$ & 17.20 & 36.84 & 26.94 & 18.48 \\
$80 \mathrm{MPa}$ & 13.47 & 32.76 & 35.48 & 18.29 \\
$100 \mathrm{MPa}$ & 13.31 & 30.59 & 37.47 & 18.63 \\
$120 \mathrm{MPa}$ & 3.72 & 42.69 & 35.13 & 19.46 \\
$140 \mathrm{MPa}$ & 5.46 & 43.25 & 31.12 & 20.17 \\
$160 \mathrm{MPa}$ & 3.79 & 43.66 & 34.01 & 18.54 \\
$180 \mathrm{MPa}$ & 3.11 & 46.83 & 29.76 & 20.30 \\
$200 \mathrm{MPa}$ & 9.95 & 46.46 & 24.87 & 19.72 \\
\hline
\end{tabular}




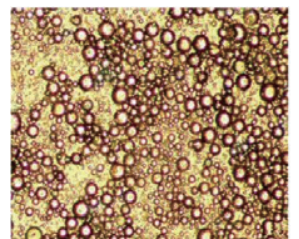

$0.1 \mathrm{MPa}$

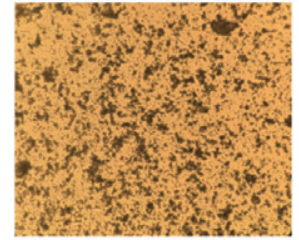

$100 \mathrm{MPa}$

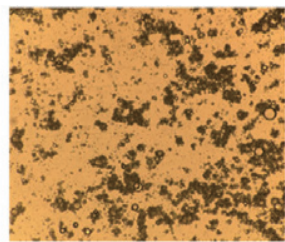

$40 \mathrm{MPa}$

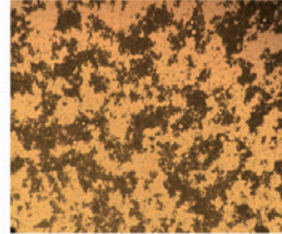

$120 \mathrm{MPa}$

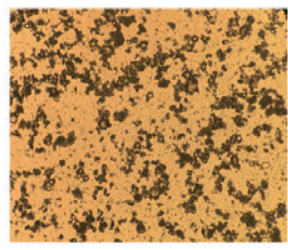

$60 \mathrm{MPa}$

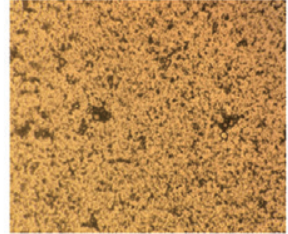

$140 \mathrm{MPa}$

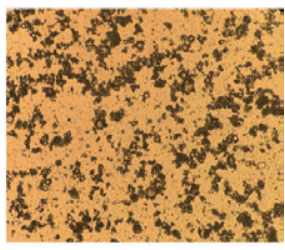

$80 \mathrm{MPa}$

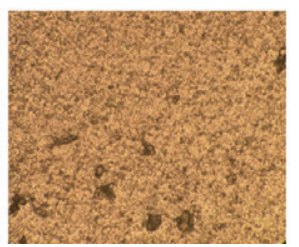

$180 \mathrm{MPa}$

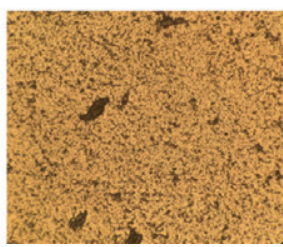

$200 \mathrm{MPa}$

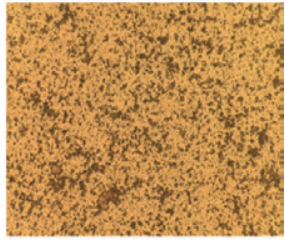

$160 \mathrm{MPa}$

Fig. 2 Optical microstructure of emulsion under different homogenization conditions (The microscope magnification of $100 \times$ was employed).

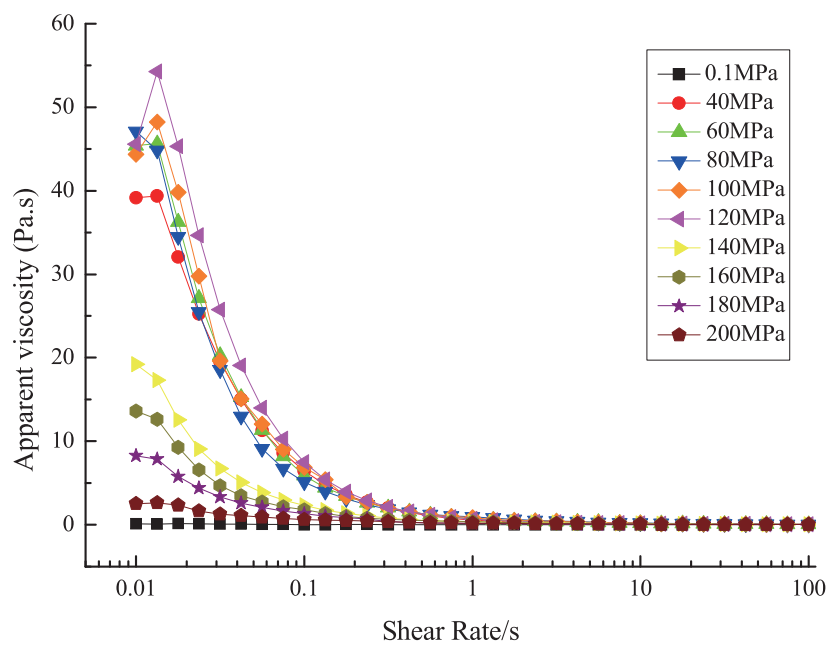

Fig. 3 Apparent Viscosity of Emulsion with Shear Rate under different homogenization pressure conditions.

axial ratio, hydration and friction ratio, and molecular shape. The shape of the protein molecule is the most important factor affecting the viscosity of the protein solution $^{38)}$. Figure 3 shows apparent viscosity of various emulsions of non-treated or HPH-treated SPI. The emulsions obtained with the untreated SPI and at low homogenization pressure (40 MPa) showed Newtonian flow behavior with quite low viscosity, less than 5 Pa.s, because there is no interaction between particles. After the emulsions treated by different $\mathrm{HPH}$ pressure above $40 \mathrm{MPa}$, they showed a clear shear thinning behavior, the apparent viscosity of the emulsions decreased rapidly with the increasing of the shear rate, then gradually becomes gentle, emulsions presented pseudoplastic fluid. That was related to the change of SPI size and the properties of SPI molecules ${ }^{39)}$. After $\mathrm{HPH}$, it is found that the average particle size of SPI emulsion was significantly reduced. As the shear flow rate increased, the hydrophilicity of the protein agglomerate particles surface increased, forming a "hydration ball", reducing the hooking of each other, reducing the resistance of the solution flow, the solution appeared shear thinning behavior. At the same shear rate, the apparent viscosity of emulsions increased with the increasing of HPH pressure and reached the maximum when the $\mathrm{HPH}$ pressure was $120 \mathrm{MPa}$, which could be explained by an increase in droplet interactions. According to the Stokes law, the sedimentation velocity of the droplet is inversely proportional to the viscosity, that is, the greater the viscosity of the emulsion, the slower the velocity of the droplets in the dispersed phase, and more stable emulsion formed. The result 


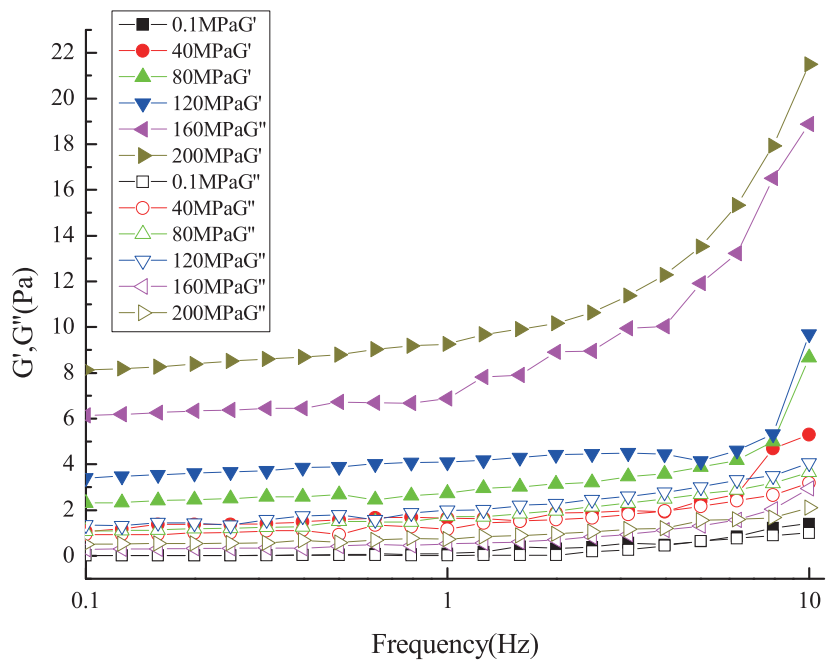

Fig. 4 The curves of the interface elastic modulus with the frequency under different homogenization pressure conditions.

is consistent with the results of Fernándezávila et $a l .{ }^{27)}$. During the process of HPH, covalent or non-covalent bonds such as hydrogen bonds, hydrophobic interactions, and electrostatic interactions can be disrupted, that could degrade the aggregation of SPI molecule and network structures. Thus, the flow properties of protein molecule increased with the increased HPH pressure.

3.6.2 Elastic modulus and viscous modulus

Elastic modulus (storage modulus) G' is an elastic energy stored in the sample, which is a measurement of the elasticity of the sample. The viscous modulus (loss modulus) G" indicates the amount of energy lost in the sample, which can be used to measure the viscosity characteristics of the sample ${ }^{40)}$. Rheological measurement of SPI emulsions were showed in Fig. 4. All emulsion's G' are larger than G", it means that the elastic properties of SPI emulsions prepared at different homogenization pressures were dominating the viscous, typical solid-like behavior was evident. No gelation or gel point was detected during the frequency sweep, which illustrated the dispersions were already in a weak gel state ${ }^{41)}$. There are significant increase in both G' and G" with increasing frequency which indicated a significant interfacial interaction among the SPI molecules. This might attribute to that as the shear frequency increases, the protein structure gradually unfolds, exposed the hydrophobic groups in the interior of the molecule. The higher the level of hydrophobicity is, the higher the intermolecular force is. The elastic modulus is a force that resists the deformation of it, so the greater the intermolecular force, the greater resistance was and the larger G' . The viscous modulus refers to the amount of energy lost by viscous deformation of the sample, thereby the greater the intermolecular force, the more energy were lost, and the larger G". We also could see that as the pressure increases,

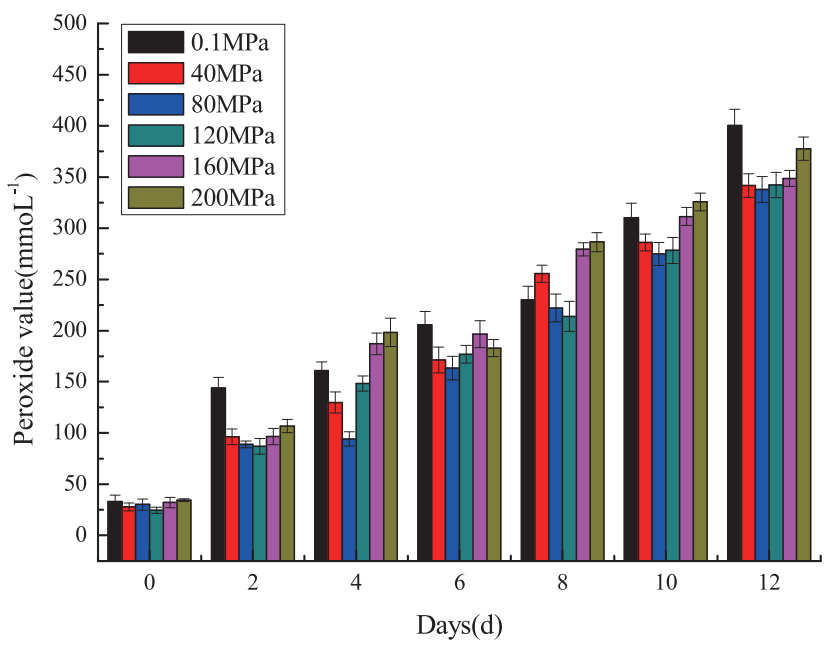

Fig. 5 Effect of HPH on peroxide value of soy protein isolate emulsions.

there are larger G' and G". This reason for that is still related to the level of hydrophobicity.

\subsection{Oxidative stability of SPI emulsions}

\subsubsection{Peroxide value}

The oxidative stability of SPI emulsions were monitored by measuring the lipid peroxide value (primary reaction products) and TBARs (secondary oxidation). During the storage of the emulsions, the peroxide value of the protein emulsions gradually increased. As it can be seen from Fig. 5 , in the first 6 days of storage, the peroxide value of the emulsions treated by HPH was lower than the emulsion stabilized by untreated protein, which means that HPH could provide a protection to hold back emulsions oxidation. After the 6th days, the protection was reduced. Malaki et $a l .{ }^{42)}$ reported that the homogenization equipment has an influence on the adsorption of SPI (in particular glycinin and $\beta$-conglycinin), which lead to different interfacial compositions. For protein emulsions, the protein directly in contact with the lipid phase (adsorbed SPI) with the interfacial area, formatting a relatively thick viscoelastic interfacial films, and protein also could chelation of metal ions, except that free radicals can be scavenged by protein ${ }^{43}$. These lead to that protein has the capacity of antioxidant, and the higher pressure is, the smaller the oil droplets are, there are greater antioxidant efficiency of the emulsions ${ }^{44}$. As the pressure increased to $120 \mathrm{MPa}$, the peroxide value increased slowly, it is might attribute that the higher pressure allowed more protein to adsorb to the surface of the emulsion droplets where it could more effectively scavenge free radicals and protect the emulsion better. Similar results were observed by O'Dwyer et al. ${ }^{45)}$, who researched that sodium caseinate was used as an emulsifier, emulsify with different oils (sunflower, camelina and fish). In their study, when the pressure ranged form 21 to $138 \mathrm{MPa}$, the 


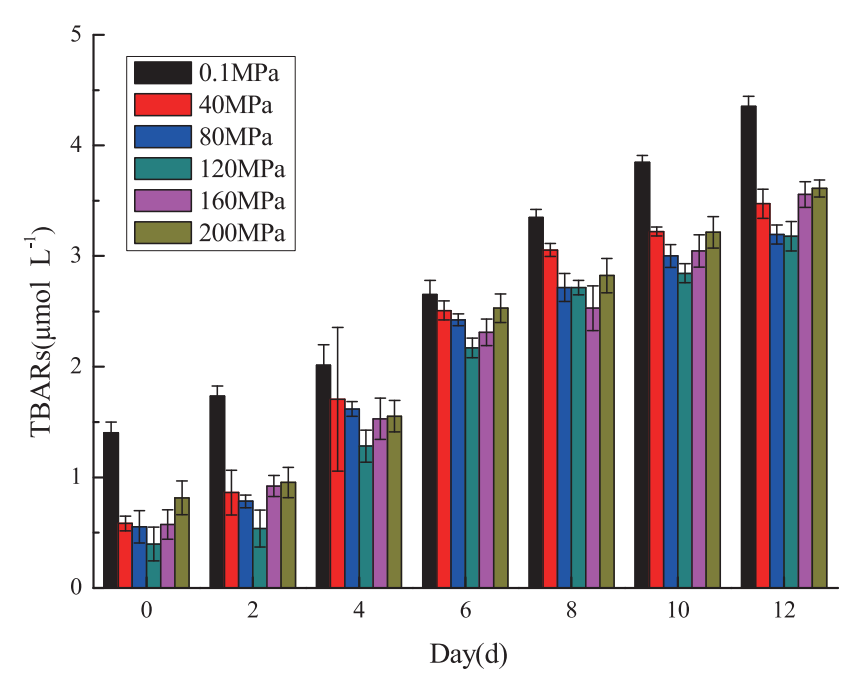

Fig. 6 Effect of HPH on TBARs of soy protein isolate emulsions.

oxidative stability of emulsions was increased. Increasing the homogenization pressure to more than $120 \mathrm{MPa}$, there is a negative effect on the oxidative stability of emulsion. There are maybe two reasons. First, the emulsions treated by $\mathrm{HPH}$ have the too small droplets and higher surface area, so more surface area was exposed to the interface $\mathrm{O} /$ $\mathrm{W}$ and lipid oxidation was accelerated. Second, the high pressure lead to an over processing phenomenon, and the emulsifying properties of SPI was decreased which reduced the ability of SPI to protect the oil droplets from oxidation. 3.7.2 The secondary oxidation of emulsions

In the case of secondary oxidation, the TBARs value of all emulsions was increased during the storage (Fig. 6). HPH-treated emulsions exhibited the highest oxidative stability in comparison to control emulsion with a lower TBARs value. It seemed that the HPH plays an important role in improving oxidative stability of emulsions. When the pressure ranged from $0.1 \mathrm{MPa}$ to $160 \mathrm{MPa}$ with same store days, the TBARs of emulsions decreased. Similar results were reported by Atarés et $a l .{ }^{46)}$ who working on O/W emulsions formulated with sun-flower oil in the presence of the flavonoid rutin and whey protein as emulsifier also found that high-pressure homogenization, through droplet size reduction, stabilized the emulsions both against creaming and oil oxidation. In addition, the excess of proteins and hydrophobic residues caused by HPH in the aqueous phase of those emulsions might have decreased lipid oxidation, by interacting with metal ions, or by scavenging free-radicals and then decreasing lipid oxidation ${ }^{18)}$. Increasing the homogenization pressure to $200 \mathrm{MPa}$, the efficiency of SPI protected the oil droplets was decreased. This may be due to SPI denatured and then do not play their stabilizing role.

\section{Conclusions}

This study evaluated the structure change, interficial properties and oxidative stability of SPI emulsions treated by different high pressure homogenization condition. Emulsifying properties, adsorbed protein percentage, SDSPAGE, FTIR, microstructure, apparent viscosity, G' , G”, peroxide value and TBARs were measured to illustrate the effects about HPH. Results showed that the HPH can improved the interface properties of the SPI emulsions, with higher adsorbed protein percentage and emulsifying properties, when the homogenization pressure does not exceed 160MPa. Meanwhile the emulsions made by HPH have the ability to slow down the process of oxidation. The results of SDS-PAGE and FTIR are also consistent with changes in interface properties. HPH has proved to be an effective method for preparation of highly viscous and stable emulsions. This information provides a theoretical basis and technical guidance for manufacturers to formulate emul-

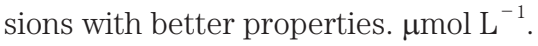

\section{Acknowledgements}

This work was supported by the National Key R\&D Program of China(2018YFD0400600) and National Soybean Industrial Technology System of China (CARS-04-PS28).

\section{References}

1) Jafari, S.M.; Assadpoor, E.; He, Y.; Bhandari, B. Re-coalescence of emulsion droplets during high-energy emulsification. Food Hydrocoll. 22, 1191-1202 (2008).

2) Herrera, M.L. Analytical techniques for studying the physical properties of lipid emulsions. Springer Briefs in Food Health, and Nutrition 3(2012).

3) McClements, D.J.; Decker, E.A.; Weiss, J. Emulsionbased delivery systems for lipophilic bioactive components. J. Food Sci. 72, R109-R124(2010).

4) Guzey, D.; Mcclements, D.J. Formation, stability and properties of multilayer emulsions for application in the food industry. Adv. Colloid Interface Sci. 128, 227-248(2006).

5) Lu, Y.; Weng, L.; Zhang, L. Morphology and properties of soy protein isolate thermoplastics reinforced with chitin whiskers. Biomacromolecules 5, 1046-1051 (2004).

6) Li Y, Chen Z, Mo H. Effects of pulsed electric fields on physicochemical properties of soybean protein isolates. LWT-Food Sci. Technol. 40, 1167-1175(2007).

7) Kim, K.M.; Weller, C.L.; Hanna, M.A. et al. Heat curing of soy protein films at selected temperatures and pressures. LWT-Food Sci. Technol. 35, 140-145 (2002).

8) Kim, K.M.; Hwang, K.T.; Weller, C.L. et al. Preparation 
and characterization of soy protein isolate films modified with sorghum wax. J. Am. Oil Chem. Soc. 79, 615-619 (2002).

9) Nishinari, K.; Fang, Y.; Guo, S. et al. Soy proteins: A review on composition, aggregation and emulsification. Food Hydrocoll. 39, 301-318(2014).

10) Li, Y.Z.; Xiao, H.Z.; Lan, L.X. Functional characterizations of SPI and its applications in food industry. China Food Additives 121-124+109 (2008). (in Chinese).

11) Kowalczyk, D.; Gustaw, W.; Świeca, M.; Baraniak, B. A study on the mechanical properties of pea protein isolate films. J. Food Process. Preserv. 38, 1726-1736 (2014).

12) Primozic, M.; Duchek, A.; Nickerson, M. et al. Formation, stability and in vitro digestibility of nanoemulsions stabilized by high-pressure homogenized lentil proteins isolate. Food Hydrocoll. 77, 126-141 (2017).

13) Diels, A.M.; Callewaert, L.; Wuytack, E.Y. et al. Inactivation of Escherichia coli by high-pressure homogenisation is influenced by fluid viscosity but not by water activity and product composition. Int. J. Food Microbiol. 101, 281-291 (2005).

14) Floury, J.; Bellettre, J.; Legrand, J. et al. Analysis of a new type of high pressure homogeniser. A study of the flow pattern. Chem. Eng. Sci. 59, 843-853(2004).

15) Wang, X.S.; Tang, C.H.; Li, B.S. et al. Effects of highpressure treatment on some physicochemical and functional properties of soy protein isolates. Food Hydrocoll. 22, 560-567(2008).

16) Xu, Y.Y.; Wang, G.R.; Wang, X.B. et al. Effects of homogenization on the molecular flexibility and emulsifying properties of soy protein isolate. Food Sci. Biotechnol. 27, 1293-1299 (2018).

17) Hebishy, E.; Buffa, M.; Juan, B. et al. Ultra high-pressure homogenized emulsions stabilized by sodium caseinate: Effects of protein concentration and pressure on emulsions structure and stability. LWT-Food Sci. Technol. 76, 57-66 (2017).

18) Fernandez-Ávila, C.; Trujillo, A.J. Ultra-High Pressure Homogenization improves oxidative stability and interfacial properties of soy protein isolate-stabilized emulsions. Food Chem. 209, 104-113 (2016).

19) Hebishy, E.; Buffa, M.; Guamis, B. et al. Physical and oxidative stability of whey protein oil-in-water emulsions produced by conventional and ultra high-pressure homogenization: Effects of pressure and protein concentration on emulsion characteristics. Innov. Food Sci. Emerg. Technol. 32, 79-90 (2015).

20) Cortésmuñoz, M.; Chevalierlucia, D.; Dumay, E. Characteristics of submicron emulsions prepared by ultrahigh pressure homogenisation: Effect of chilled or frozen storage. Food Hydrocoll. 23, 640-654 (2009).

21) Desrumaux, A.; Marcand, J. Formation of sunflower oil emulsions stabilized by whey proteins with high-pres- sure homogenization (up to $350 \mathrm{MPa}$ ): Effect of pressure on emulsion characteristics. Int. J. Food Sci. Technol. 37, 263-269 (2002).

22) Sorgentini, D.A.; Wagner, J.R. Comparative study of structural characteristics and thermal behavior of whey and isolate soybean proteins. J. Food Biochem. 23, 489-507 (2010).

23) Tang, S.; Hettiarachchy, N.S.; Horax, R. et al. Physicochemical properties and functionality of rice bran protein hydrolyzate prepared from heat-stabilized defatted rice bran with the aid of enzymes. J. Food Sci. 68, 152-157 (2006).

24) Laemmli, U.K. Cleavage of structural proteins during the assembly of the head of bacteriophage T4. Nature 227, 680-685 (1970).

25) Shao, Y.; Tang, C.H. Characteristics and oxidative stability of soy protein-stabilized oil-in-water emulsions: Influence of ionic strength and heat pretreatment. Food Hydrocoll. 37, 149-158(2014).

26) Sørensen, G.; Jørgensen, S.S. A critical examination of some experimental variables in the 2-thiobarbituric acid (TBA) test for lipid oxidation in meat products. $Z$. Lebens. Unters. Forsch. 202, 205-210(1996).

27) Fernándezávila, C.; Escriu, R.; Trujillo, A.J. Ultra-High Pressure Homogenization enhances physicochemical properties of soy protein isolate-stabilized emulsions. Food Res. Int. 75, 357-366 (2015).

28) Floury, J.; Desrumaux, A.; Legrand, J. Effect of ultrahigh-pressure homogenization on structure and on rheological properties of soy protein-stabilized emulsions. J. Food Sci. 67, 3388-3395(2002).

29) Dong, X.; Zhao, M.; Yang, B. et al. Effect of high-pressure homogenization on the functional property of peanut protein. J. Food Process Eng. 34, 2191-2204 (2011).

30) Bader, S.; Bez, J.; Eisner, P. Can protein functionalities be enhanced by high-pressure homogenization? - A study on functional properties of lupin proteins. Procedia Food Sci. 1, 1359-1366 (2011).

31) Bouaouina, H.; Desrumaux, A.; Loisel, C. et al. Functional properties of whey proteins as affected by dynamic high-pressure treatment. Int. Dairy J. 16, 275284 (2006).

32) Saricaoglu, F.T.; Gul, O.; Besir, A. et al. Effect of High Pressure Homogenization ( $\mathrm{HPH}$ ) on functional and rheological properties of hazelnut meal proteins obtained from hazelnut oil industry by-products. J. Food Eng. 233, 98-108(2018).

33) Subirade, M.; Loupil, F.; Allain, A.F.; Paquin, P. Effect of dynamic high pressure on the secondary structure of beta-lactoglobulin and on its conformational properties as determined by Fourier transform infrared spectroscopy. Int. Dairy J. 8, 738-744(1998).

34) Puppo, M.C.; Chapleau, N.; Speroni, F. et al. Physico- 
chemical modifications of high-pressure-treated soybean protein isolates. J. Agric. Food Chem. 52, 15641571(2004).

35) McClements, D.J.; Monahan, F.J.; Kinsella, J.E. et al. Disulfide bond formation affects stability of whey protein isolate emulsions. J. Food Sci. 58, 1036-1039 (1993).

36) Kuhn, K.R.; Cunha, R.L. Flaxseed oil - Whey protein isolate emulsions: Effect of high pressure homogenization. J. Food Eng. 111, 449-457 (2012).

37) Chen, L.; Chen, J.;Ren, J. et al. Effects of ultrasound pretreatment on the enzymatic hydrolysis of soy protein isolates and on the emulsifying properties of hydrolysates. J. Agric. Food Chem. 59, 2600-2609 (2011).

38) Kinsella, J.E. Functional properties of soy proteins. $J$. Am. Oil Chem. Soc. 56, 242-258(1979).

39) Song, X.Z.; Zhou, C.J.; Fu, F. et al. Effect of high-pressure homogenization on particle size and film; properties of soy protein isolate. Ind. Crops Prod. 43, 538$544(2013)$.

40) Yuvaret, V.; Achayuthakan, P.; Suphantharika, M. Gelatinization and rheological properties of rice/xanthan mixtures. Food Chem. 111, 106-114(2008).

41) Ahmed, J.; Al-Ruwaih, N.; Mulla, M. et al. Effect of high pressure treatment on functional, rheological and structural properties of kidney bean protein isolate. LWT-Food Sci. Technol. 91, 191-197(2018).

42) Malaki, N.A.; Wright, A.J.; Corredig, M. Impact of interfacial composition on emulsion digestion and rate of lipid hydrolysis using different in vitro digestion models. Colloids Surf. B 83, 321-330(2011).

43) Osborn, H.T.; Akoh, C.C. Effects of natural antioxidants on iron-catalyzed lipid oxidation of structured lipid-based emulsions. J. Am. Oil Chem. Soc. 80, 847852 (2003).

44) Lethuaut, L.; Metro, F.; Genot, C. Effect of droplet size on lipid oxidation rates of oil-in-water emulsions stabilized by protein. J. Am. Oil Chem. Soc. 79, 425-430 (2002).

45) O’ Dwyer, S.P.; O’Beirne, D.; Ní Eidhin, D. et al. Formation, rheology and susceptibility to lipid oxidation of multiple emulsions (O/W/O) in table spreads containing omega-3 rich oils. LWT-Food Sci. Technol. 51, 484-491 (2013).

46) Atarés, L.; Marshall, L.J.; Akhtar, M. et al. Structure and oxidative stability of oil in water emulsions as affected by rutin and homogenization procedure. Food Chem. 134, 1418-1424(2012). 